\title{
Presentation av Eva Silvén
}

Eva Silvén är fil. dr i etnologi vid Stockholms universitet och intendent vid Nordiska museet. Parallellt med sin verksamhet som museipraktiker har hon kontinuerligt arbetat med museivetenskapliga frågor. Idag ligger hennes forskningsintressen inom fält som materialitet, etiska och andra kritiska frågor rörande museer och kulturarv samt samlingars och samlandets sociala och materiella dynamik.

1989-2003 var Eva Silvén ansvarig för Samdoksekretariatet, navet i det svenska museinätverket för samtidsinriktad dokumentation och insamling, knutet till Nordiska museet. Där verkade hon för att utveckla teori, metod och organisation samt inrättade ett forskningsråd med representanter från universitet och högskolor. Hon var redaktör för nätverkets tidskrift och en serie metodologiska handböcker, baserade på årliga kurser och seminarier. Hon var också medförfattare till ett par antologier efter några självreflekterande och kritiskt problematiserande projekt, bland dem Sambällsideal och framtidsbilder. Perspektiv på Nordiska museets insamling och forskning (2004) och Svåra saker. Ting och berättelser som upprör och berör (2006). Den senare väckte stor uppmärksamhet genom sin inriktning på i olika avseenden problematiska föremål och genom att ställa frågan om museernas vilja (eller ovilja) att engagera sig i livets mörka och mer komplicerade sidor. Projektet tog också formen av en vandringsutställning, där besökarna inbjöds att bidra med sina egna "svåra" saker och berättelser.

Under samma period arbetade Eva Silvén

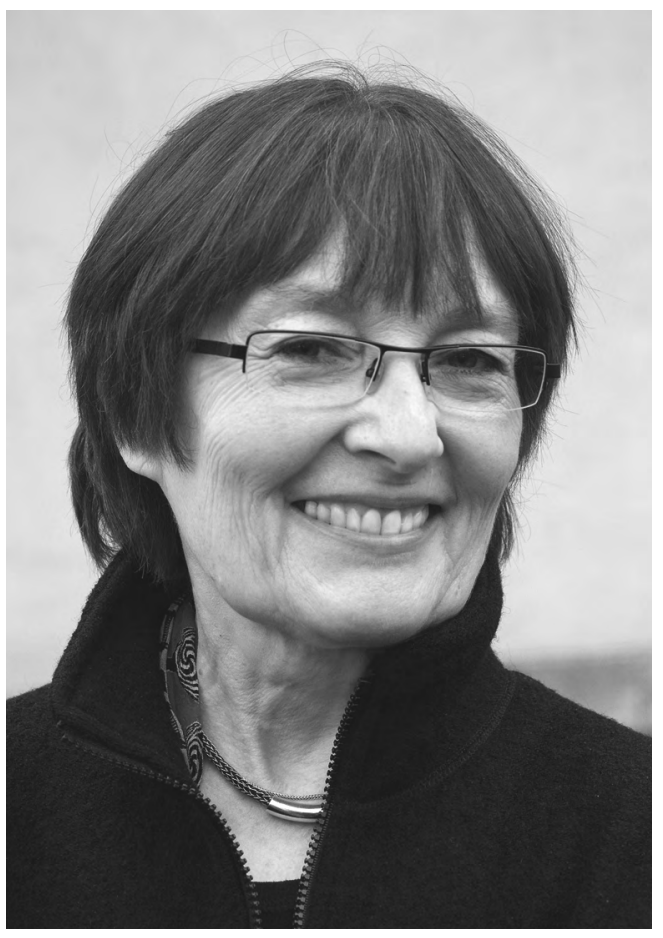

Eva Silvén

med sin doktorsavhandling om byggnadsmålares konstruktion av yrkesidentitet: Bekänna färg. Modernitet, maskulinitet, professionalitet (2004). Analysen baserades dels på ett års fältarbete på en byggarbetsplats med fokus på kropp, materialitet, process och performans, dels på bruket av historia och kulturarv i media och museer.

Efter 2004 har Eva Silvén huvudsakligen arbetat med minoritets- och mångfaldsfrågor 
Presentation

på Nordiska museet, innefattande nationella minoriteter och urfolk, som samerna. Ur dessa perspektiv har hon bland annat publicerat några korta översikter av museets historia, från öppnandet 1873 till idag: "Cultural diversity at the Nordiska Museet in Stockholm: Outline of a story" (i Goodnow, Katherine \& Akman, Haci, red. Scandinavian museums and cultural diversity, 2008) och "Lapps and Sami - narrative and display at the Nordiska Museet" (i Andersson, Kajsa, red. L'Image du Sápmi. Études comparées, 2009.) Hon har också varit verksam inom olika forskningsråd, styrelser och nätverk vid museer och universitet. Sedan 1998 har hon varit medlem av den svenska delen av Nordisk Museologis redaktionsråd.

För tillfället arbetar Eva Silvén med forskningsprojektet Konstruktionen av ett samiskt kulturarv: Ernst Manker och Nordiska museet, finansierat av Riksbankens Jubileumsfond (2009-11). Ernst Manker utsågs 1939 till den förste intendenten med särskilt ansvar för museets samiska samlingar. Med syftet att skapa "ett centralmuseum för den lapska kulturen" inledde han en intensiv forskning, dokumentation och insamling, och 1947 öppnades en ny samisk basutställning som kom att stå kvar i trettio år. Projektets syfte är att undersöka vilken roll denna verksamhet kan ha spelat i sin samtid, en tid då det samiska samhället var i stark omvandling. Bidrog museiskapandet till att legitimera samernas strävan efter moderna livsformer och nya rättigheter, genom att pietetsfullt göra kulturarv av avlagda kläder och bruksföremål? Eller kom den historieinriktade museirepresentationen att låsa bilden av samtidens samer vid det förgångna? Genom att förbinda Mankers verksamhet med dagens situation är ambitionen att med ett historiskt exempel bidra till det internationella forskningsfältet med ny kunskap om hur för- hållandet mellan etniska gruppers kulturella erkännande och sociala och politiska rättigheter kan gestalta sig.

Eva Silvén, fil.dr, intendent

Adress: Nordiska museet

Box 27820

SE-11593 Stockholm, Sverige

E-mail:eva.silven@nordiskamuseet.se 